PRINT ISSN 1119-8362

Electronic ISSN 1119-8362
Full-text Available Online at https://www.ajol.info/index.php/jasem

http://ww.bioline.org.br/ja
J. Appl. Sci. Environ. Manage.

Vol. 24 (8) 1463-1466 August 2020

\title{
Characterization of Autochthonous Bacterial Isolates with The Potentiality to Degrade Spent Engine Oil from Contaminated Soil Area Enriched with Glycine max
}

\section{${ }^{* 1}$ ENAIGBE, AA; ${ }^{1}$ IMADE OS; ${ }^{1}$ AKPOKA, OA; ${ }^{1}$ UFUAH E; ${ }^{1}$ IZEVBUWA, OE; ${ }^{2}$ OKHUEBOR, SO}

\author{
${ }^{*}$ Department of Biological Sciences, College of Applied and Natural Sciences, Igbinedion University, Okada, Nigeria. \\ ${ }^{2}$ Department of Microbiology, Faculty of Life Sciences, University of Benin, Nigeria \\ *Corresponding Author Email: andrewenaigbe89@gmail.com; Tel.: +2348131230105
}

\begin{abstract}
This study was conducted to identify and characterize bacteria capable of degrading spent oil contaminated soil. The physicochemical parameters of used engine oil were analyzed according to existing standards, while the total heterotrophic plate counts (HBC) and hydrocarbon utilizing bacteria counts were ascertained with the pour plate methods using nutrient agar and minimal salt agar (MSA) media respectively. The results indicated a mean total $\mathrm{HBC}$ ranging from $2.86 \pm 0.08$ to $5.76 \log _{10} \mathrm{CFU} / \mathrm{g}$ and mean hydrocarbon utilizing bacterial counts from $1.32 \pm 0.09$ to $3.82 \pm 0.25 \log _{10} \mathrm{CFU} / \mathrm{g}$, with samples enriched with Glycine max (Soybean) recorded to have the highest bacterial counts. The phenotypic identification of the hydrocarbon utilizing bacteria as sources of carbon and energy showed the presence of two primary bacterial genera: Bacillus and Micrococcus. However, from the overall 50 counted colonies, the frequency of occurrence for Bacillus was $41(82 \%)$ whereas, the Micrococcus was (9) 18\%. The obtained data, confirmed the breakdown capacity of autochthonous (indigenous) organisms notably; Bacillus in the reduction of pollutants linked with oil spillage. This provides for reliable and promising approach of ameliorating crude oil pollutants and its inherent threats.
\end{abstract}

\section{DOI: https://dx.doi.org/10.4314/jasem.v24i8.23}

Copyright: Copyright $(\subset) 2020$ Enaigbe et al. This is an open access article distributed under the Creative Commons Attribution License (CCL), which permits unrestricted use, distribution, and reproduction in any medium, provided the original work is properly cited.

Dates: Received: 30 May 2020; Revised: 03 July 2020; Accepted: 05 August 2020

Keywords: Soil, spent oil, Glycine max, degrading bacteria, isolation and bioremediation

Spent engine oil or used motor oil abounds in oil mechanic workshops and industrial sources that may occur as hydraulic oil, turbine, process and brake oils and consists of large number of long-chain saturated hydrocarbons. The crude oil is a mixture of hydrocarbon and hydrocarbon-like, polycyclic aromatic hydrocarbons (PAHs) and heavy metals (Cappello et al., 2007). The contamination and eventual pollution of the environment have raised an issue of global interest due to their widespread distribution and multiple threats on the ecosystem especially, their toxicological impacts on human beings, plants and other organisms (Ohenhen et al., 2006). The abilities of certain microorganisms such as Bacillus, Pseudomonas, Acinobacter and Flavobacillus to breakdown crude oil and its products had been previously reported (Omoni and Abu, 2004). Subsequently, these degrading organisms possess specific enzyme systems that enable them to utilize hydrocarbons as their carbon and energy sources. Nevertheless, there is a concerted effort by the scientific communities in reducing pollutants from crude oil spill through the cost-effective and promising approach known as bioremediation (Barathi and
Vasudevan, 2001). This is the use of microorganisms to get rid of harmful substances from the environment by transforming them into less toxic, harmless and useful products (Emetola, 2018).

The aim of this study is to determine bacterial isolates capable of utilizing spent oil contaminated soil enriched with Glycine max as source of carbon and energy.

\section{MATERIALS AND METHODS}

Sample Collections: One kilogram of soil sample contaminated with spent engine oil was obtained from a motor mechanic workshop along Mission Road, in Okada, Ovia North East Local Government Area, Edo State. Ten grams $(10 \mathrm{~g})$ of the contaminated soil sample from the sampling site was blended with soybean, measured into 2 polyethene bags, label A and B. Another $10 \mathrm{~g}$ of the contaminated spent engine oil was taken into 2 other polyethene bags as samples $\mathrm{C}$ and $\mathrm{D}$, while an uncontaminated soil sample was collected from the Igbinedion University, Okada botanical garden. The 5 samples were transported to

*Corresponding Author Email: andrewenaigbe89@gmail.com; Tel.: +2348131230105 
the Department of Microbiology Laboratory, Igbinedion University for microbiological analysis.

Physicochemical analysis of soil samples: Ten grams $(10 \mathrm{~g})$ each of samples A, B, C, D and E as measured above were also collected for the determination of physicochemical analysis. After eliminating the debris and other hard particles therein, the 5 samples were stored in McCartney bottles and were immediately transported to Nigeria Institute for oil-palm Research (NIFOR) for analysis. The parameters measured include $\mathrm{pH}$, moisture content, turbidity, electrical conductivity, total organic carbon (TOC); total nitrogen, polycyclic aromatic hydrocarbons (toluene, naphthalene, phenaphthalene) heavy metals (lead and iron) and were determined using standard methods (APHA, 2015).

Isolation and Enumeration of bacteria: Isolation of bacteria from spent engine oil contaminated soil samples was performed according to methods established (Atlas, 2004; Udeani et al., 2009). The total heterotrophic bacterial count (HBC) was determined by the pour plate technique on nutrient agar. One gram of soil sample was aseptically introduced onto $9 \mathrm{ml}$ of sterile peptone water, thoroughly shaken and serially diluted. Aliquot (0.1 $\mathrm{ml}$ ) of $10^{-1}$ to $10^{-4}$ dilution factors were inoculated on sterile plates containing nutrient agar. The plates were incubated at room temperature, while the distinct bacterial colonies developed in the nutrient agar plates were counted and used to deduce the heterotrophic bacteria load.

Identification and characterization: Individual bacterial colonies were picked based on different colony morphology and color and further sub-cultured by pouring onto fresh nutrient agar slants and incubated at room temperature for $48 \mathrm{hr}$. The colonies were repeatedly poured on agar slants until pure cultures were obtained and identified. Gram staining was carried out to differentiate the bacterial isolates into gram positive and negative bacteria according to standardized protocol (Atlas, 2004; Omoni and Abu, 2014). The following biochemical tests were performed to characterize and to further identify the isolated organisms; catalase, citrate, indole, lactose, methyl red and oxidase (APHA, 2015).

Enumeration of total hydrocarbon utilizing bacteria: The total hydrocarbon utilizing bacteria was cultured on minimal salt agar (MSA) using the pour plate method as prescribed by Atlas (2004) and modified by Udeani et al., 2009. Ten-fold serial dilutions were performed on the spent engine oil and $1 \mathrm{ml}$ of each dilution was mixed with $20 \mathrm{ml}$ of sterile MSA in a plate, incubated at $30{ }^{\circ} \mathrm{C}$ for $72 \mathrm{hr}$. The bacterial colonies on agar plates were then counted and subsequently expressed as hydrocarbon utilizing bacteria per $\mathrm{ml}$ of spent oil. Thereafter, the colonies were randomly picked and streaked onto sterile nutrient agar slants in McCartney bottles. The pure isolates were then stored in the refrigerator at $-4{ }^{\circ} \mathrm{C}$ for further analysis.

Identification and characterization of hydrocarbon utilizing bacteria: The isolates were identified and characterized using morphological and biochemical tests respectively (Mandigan et al., 2017).

\section{RESULTS AND DISCUSSION}

This represents the counts of total heterotrophic bacteria (THC) in the soil samples. The mean THC were respectively estimated at $2.86 \pm 0.08 \log _{10}$ $\mathrm{CFU} / \mathrm{g}, 5.18 \pm 0.11 \log _{10} \mathrm{CFU} / \mathrm{g}$ and $5.76 \pm 0.26 \log _{10}$ $\mathrm{CFU} / \mathrm{g}$ for the uncontaminated soil, engine oilcontaminated soil and engine oil-contaminated soil enriched with Glycine max. The count of hydrocarbonutilizing fraction of the total heterotrophic bacteria in the soil samples are presented in Table 3. Using spent engine oil as the sole carbon source, the hydrocarbonutilizing bacteria counts were respectively $1.32 \pm 0.09$ $\log _{10} \mathrm{CFU} / \mathrm{g}, 3.31 \pm 0.12 \log _{10} \mathrm{CFU} / \mathrm{g}$ and $3.82 \pm 0.25$ $\log _{10} \mathrm{CFU} / \mathrm{g}$ for uncontaminated soil, engine oilcontaminated soil and engine oil-contaminated soil enriched with Glycine $m$

Table 1: Physicochemical analysis of soil samples contaminated with spent oil.

\begin{tabular}{|c|c|c|c|c|c|c|c|c|c|c|c|c|}
\hline \multirow{2}{*}{ Samples } & \multicolumn{12}{|c|}{ Parameters } \\
\hline & PA & pH & MC & TUR & $\mathbf{O M}$ & TN & TOC & $\mathbf{F e}$ & PB & NAP & TOL & $\mathbf{A C}$ \\
\hline SA & LM & 4.71 & 2.10 & ND & 2.17 & 35.5 & 10.2 & ND & ND & ND & ND & ND \\
\hline SB & LM & 4.92 & 2.15 & ND & 3.0 & 30.0 & 15.0 & ND & ND & ND & ND & ND \\
\hline $\mathrm{SC}$ & LH & 5.70 & 1.75 & 10.0 & 3.55 & 2.16 & 35.0 & 0.06 & 0.29 & ND & 20.0 & 0.03 \\
\hline SD & LH & 5.03 & 2.0 & 6.81 & 3.26 & 2.01 & 40.0 & 0.02 & 0.20 & ND & 13.9 & 0.01 \\
\hline $\mathrm{SE}$ & LH & 6.90 & 1.64 & 0.05 & 4.45 & 1.50 & 29.0 & ND & ND & ND & ND & 0.01 \\
\hline
\end{tabular}


Table 2: Counts of total heterotrophic bacteria in the soil samples

\begin{tabular}{lllllll} 
& \multicolumn{5}{c}{ Counts of total heterotrophic bacteria (THC) } \\
\cline { 2 - 7 } Sample & \multicolumn{2}{c}{ Uncontaminated soil } & \multicolumn{3}{c}{ Contaminated soil } & \multicolumn{2}{c}{ Contaminated soil + GM } \\
\cline { 2 - 7 } & Count & Mean \pm SE count & Count & Mean \pm SE count & Count & Mean \pm SE count \\
& $\mathbf{N = 1}$ & $\mathbf{N = 5}$ & $\mathbf{N = 1}$ & $\mathbf{N}=\mathbf{5}$ & $\mathbf{N}=\mathbf{1}$ & $\mathbf{N}=\mathbf{5}$ \\
& $\mathbf{L o g}_{\mathbf{1 0}} \mathbf{C F U} / \mathbf{g}$ & $\mathbf{L o g}_{\mathbf{1 0}} \mathbf{C F U} / \mathbf{g}$ & $\mathbf{L o g}_{\mathbf{1 0}} \mathbf{C F U} / \mathbf{g}$ & $\mathbf{L o g}_{\mathbf{1 0}} \mathbf{C F U} / \mathbf{g}$ & $\mathbf{L o g}_{\mathbf{1 0}} \mathbf{C F U} / \mathbf{g}$ & $\mathbf{L o g} \mathbf{1 0} \mathbf{C F U} / \mathbf{g}$ \\
\hline 1 & 2.60 & & 5.19 & & 5.45 & \\
2 & 2.85 & & 4.92 & & 5.59 & $5.76 \pm 0.26$ \\
3 & 3.02 & $2.86 \pm 0.08$ & 5.51 & $5.18 \pm 0.11$ & 6.78 & \\
4 & 2.83 & & 5.30 & & 5.51 & \\
5 & 2.99 & & 5.00 & & 5.48 & \\
\hline
\end{tabular}

Key: GM: Glycine max; N: total number of samples examined; SE: standard error of mean; CFU/g: coliform forming unit per gram

Table 3: Counts of hydrocarbon-utilizing bacteria in the soil sample

\begin{tabular}{|c|c|c|c|c|c|c|}
\hline \multirow[b]{3}{*}{ Sample } & \multicolumn{6}{|c|}{ Counts of total heterotrophic bacteria (THC) } \\
\hline & \multicolumn{2}{|c|}{ Uncontaminated soil } & \multicolumn{2}{|c|}{ Contaminated soil } & \multicolumn{2}{|c|}{ Contaminated soil + GM } \\
\hline & $\begin{array}{l}\text { Count } \\
N=1 \\
\log _{10} \text { CFU/g }\end{array}$ & $\begin{array}{l}\text { Mean } \pm \text { SE count } \\
\mathrm{N}=5 \\
\mathrm{Log}_{10} \mathrm{CFU} / \mathrm{g}\end{array}$ & $\begin{array}{l}\text { Count } \\
N=1 \\
\log _{10} \text { CFU/g }\end{array}$ & $\begin{array}{l}\text { Mean } \pm \text { SE count } \\
N=5 \\
\log _{10} C F U / g\end{array}$ & $\begin{array}{l}\text { Count } \\
N=1 \\
\log _{10} \text { CFU/g }\end{array}$ & $\begin{array}{l}\text { Mean } \pm \text { SE count } \\
N=5 \\
\log _{10} C F U / g\end{array}$ \\
\hline 1 & 1.12 & & 3.13 & & 3.63 & \\
\hline 2 & 1.18 & & 2.95 & & 3.50 & \\
\hline 3 & 1.40 & $1.32 \pm 0.09$ & 3.62 & $3.31 \pm 0.12$ & 4.81 & $3.82 \pm 0.25$ \\
\hline 4 & 1.29 & & 3.51 & & 3.59 & \\
\hline 5 & 1.62 & & 3.33 & & 3.56 & \\
\hline
\end{tabular}

Table 4: Phenotypic characterization of hydrocarbon-utilizing bacterial colonies obtained from the contaminated soil samples

\begin{tabular}{|c|c|c|c|c|c|c|c|c|c|c|c|c|}
\hline \multirow[t]{2}{*}{$\begin{array}{l}\text { Carbon } \\
\text { Source }\end{array}$} & \multirow[t]{2}{*}{$\begin{array}{l}\text { Representative } \\
\text { Isolates }\end{array}$} & \multicolumn{2}{|c|}{$\begin{array}{l}\text { Colony and Morphological } \\
\text { characteristics }\end{array}$} & \multicolumn{6}{|c|}{ Biochemical Characteristics } & \multirow[t]{2}{*}{$\begin{array}{l}\text { Identified } \\
\text { isolates }\end{array}$} & \multicolumn{2}{|c|}{$\begin{array}{l}\text { Relative } \\
\text { occurrence of the } \\
\text { hydrocarbon- } \\
\text { utilizing bacteria }\end{array}$} \\
\hline & & $\begin{array}{l}\text { Colony } \\
\text { characteristics }\end{array}$ & $\begin{array}{l}\text { Gram } \\
\text { staining }\end{array}$ & Co & $\mathbf{C a}$ & $\mathbf{O x}$ & Mr & $\mathbf{V p}$ & Ht & & $\mathbf{F}$ & $\%$ \\
\hline \multirow{2}{*}{$\begin{array}{l}\text { Engine } \\
\text { Oil }\end{array}$} & 1 & Dry colonies & $\begin{array}{l}\text { Positive } \\
\text { rods }\end{array}$ & - & + & - & - & + & $\beta$ & Bacillus & $\begin{array}{l}41 / 5 \\
0\end{array}$ & 82.00 \\
\hline & 2 & $\begin{array}{l}\text { Mucoid } \\
\text { colonies }\end{array}$ & $\begin{array}{l}\text { Positive } \\
\text { cocci }\end{array}$ & - & + & + & + & - & $\beta$ & Micrococcus & $9 / 50$ & 18.00 \\
\hline
\end{tabular}

haemolytic bacterial colony.

The phenotypic characterization of hydrocarbonutilizing bacterial colonies isolated from the contaminated soil samples is presented in Table 4. The identified hydrocarbon-utilizing bacteria were Bacillus and Micrococcus species. Bacillus species were the hydrocarbon-utilizing bacteria that most frequently occurred in the contaminated soil samples. The analysis of the physicochemical parameters revealed the average $\mathrm{pH}$ values from 4.71 to 6.90 and signified that all soil samples were acidic, with SA being the most acidic (4.71) (Table 1). However, soil acidity could be attributed to the carbonic acid formed when the carbon fraction of the hydrocarbon might have been hydrolyzed resulting in bicarbonate ions (HCO3-) in soil samples. More so, increased acidity and total nitrogen depend on the activities of nitrifying bacteria in soil (Ewetola, 2018). This is influenced by the presence of dissolved oxygen in an enzymatic reaction during nitrification process to produce nitric acid that tend to increase the $\mathrm{pH}$ of the soil. Low $\mathrm{pH}$ causes metals to precipitate as carbonate and hydroxyl ions that can lead to irritation of the skin and eye when in contact with used oil in polluted sites. The concentrations of iron $(\mathrm{Fe})$ were detected in SC $(0.06$ $\mathrm{mg} / \mathrm{g})$ and $\mathrm{SD}(0.02 \mathrm{mg} / \mathrm{g})$ (Table 1). Contact and accumulation of iron in body result to a disease condition referred to as hemochromatosis (Iron overload disease) cirrhosis, nausea, vomiting and surface stains. Additionally, the concentrations of lead $(\mathrm{Pb})$ were recorded in $\mathrm{SC}(0.29 \mathrm{mg} / \mathrm{g}) \mathrm{SD}(0.20 \mathrm{mg} / \mathrm{g})$ and exceeded the recommended threshold $(0.01$ $\mathrm{mg} / \mathrm{g}$ ). Excess lead has been linked to cancer, kidney and liver malfunction, low blood haemoglobin and high blood pressure (Kvenovolden and Cooper, 2019). The results of PAHs analyses (Table 1) revealed that naphthalene was not detected in any of the soils, $\mathrm{C}$ and $\mathrm{D}$ recorded high concentrations of toluene 0.29 and $0.20 \mathrm{mg} / \mathrm{g}$ respectively and acenaphthalene concentrations ranged from 0.01 to $0.03 \mathrm{mg} / \mathrm{g}$ in C, D and $\mathrm{E}$. This indicated that, toluene and acenaphthalene were always present in spent oil contaminated soils (C and D). It has been reported that toluene is irritating to the eye, skin and respiratory tract, causes systemic toxicity by ingestion or inhalation and could damage 
the kidney, liver, lung and impaired immune function (Mandigan et al., 2017). The levels of adaptation of microbial communities to and transformation of hydrocarbons associated with oil polluted environments have been reported to be on increase in many studies (Barathi and Vasudevan, 2001). This finding is in diadem with earlier remarks which indicated the wide distribution of existence of Pseudomonas and Bacillus species in contaminated sites. Among the endowed metabolic properties enabling them to degrade these compounds include; tolerance to high concentrations of solvents, embodiment of complimentary metabolic capacity through rapid alteration and the exchange of genetic material, possession of specific enzyme system for oxidation of organic compounds by which molecular oxygen is incorporated by dioxygenases to form cisdihydrodiols. The intermediates of dihydrodiol dehydrogenation are metabolized into carbon dioxide and water through the catechols by the action of catechol dioxydrogenases and other enzymes (Chikere et al., 2011; Akpoka et al., 2020). Consequently, from the pool of the total heterotrophic bacteria count, the $\mathrm{HBC}$ mean ranged from $2.86+0.08 \log _{10} \mathrm{CFU} / \mathrm{g}$ to $5.76+0.26 \log _{10} \mathrm{CFU} / \mathrm{g}$ with the highest HBC count $\left(5.76+0.26 \log _{10} \mathrm{CFU} / \mathrm{g}\right)$ recorded from contaminated soil enriched with Glycine max and lowest count was obtained from the uncontaminated soil (Table 2). Subsequently, the mean hydrocarbon utilizing bacteria counts ranged from $1.32+0.09$ to $3.82+0.25 \log _{10}$ $\mathrm{CFU} / \mathrm{g}$, with the highest count also recorded from the contaminated soil blended with G. max. According to Ewetola (2018), the increase in bacteria load of the contaminated soil blended with G. $\max$ could be adduced to the rich composition of proteins, B-group vitamins (cobolamin and tocopherol) minerals and plant compound such as isoflavones that can enhance the growth of hydrocarbon breaking organisms.

These potential genera (Bacillus and Micrococcus) were selected based on their abilities to utilize crude oil as their carbon source, identified and characterized by biochemical tests. The screening results showed that Bacillus genus was the predominated hydrocarbon degrader in spent engine oil environment with relative prevalence of 41 from total of 50 samples surveyed, indicating $82 \%$, compared to the Micrococcus with frequency of $9(18 \%)$ (Table 4$)$. The Bacillus has been implicated in abscesses, septicaemia, osteomylitis, wound and burn infections, while infections caused by Micrococcuus include; bacteremia, pneumonia, systemic arthritis and peritonitis (Udeani et al., 2009; Mandigan et al., 2017). The strain Lysinbacillus sphaericus A-3-10 in bioremediation, has been identified to possess the potential to reversibly bind heavy metals such as lead, copper, cadmium and uranium due to the presence of the proteinaceous surface overlying the bacteria cell, called the S-layer (Cappello et al., 2007).

Conclusion: The ability of autochthonous active bacteria in spent oil to utilize hydrocarbon as their sole source of carbon enhances healthy environment and economical process for curbing crude oil contamination and necessary for the recovery of sites polluted with hydrocarbon contaminants of the affected ecosystems.

\section{REFERENCES}

Akpoka, OA; Erifeta, GO; Imade, OS; Okafor-Elenwo, EJ (2020). Isolation and characterization of crude oil degrading bacteria in association with micro algae in saver pit from Egbaoma flow station, Niger State, Nigeria. Arch. Ecotox. 2 (2): 12 - 16.

America Public Health Association (APHA) (2005). Standard Methods for Examination of Water and Waste water (22 ed.) Washington, D.C., p. 311.

Atlas, RM (2004). Standard Methods for Water Effluent Analysis. Univ. Pr. Ibadan, p. 225.

Barathi, S; Vasudevan, N (2001).Utilization of petroleum hydrocarbons by Pseudomonas flourescens isolated from petroleum contaminated soil. Env. Int. 26: 413 416.

Cappello, S; Caruso, G; Sampino, D; Guiliano, L (2007). Microbial community dynamics during assays of harbor oil spill remediation. J. Appl. Microb. 102(1): 184 - 194.

Chikere, CB; Okpokwasili, GC; Chikere, BO (2011). Monitoring of microbial hydrocarbon remediation in soil. Biotechn. 1(13): 117 -137.

Ewetola, A (2018). Effects of tillage and leguminous species on soil properties. J. Nat. Sc. Ann. Microb. Res. 6: 12 18.

Kvenovolden, KA; Cooper, CK (2019). Natural seepage of crude oil into the marine environment. Geo Mar. Let. 23(3): $140-146$.

Madigan, TM; Martinko, MJ; Parker, J (2017). Biology of Microorganisms ( $8^{\text {th }}$ ed.) Prentice Hall Int. Inc, p. 986.

Ohenhen, ER; Ikolo, FE; Uzeh, ER (2006). Growth response of bacterial isolates on crude oil. Am. J. Sc. 2(2): 13 -16.

Omoni, VT; Abu, GO (2004). Laboratory cultivation of microalgae using novel media formations. Int. J. Env. Bioeng. 9(1): $56-75$.

Udeani, TK; Obroh, AA; Okwuoso, CN; Achukwu, PU (2009). Isolation of bacteria from soil contaminated with engine oil. Af. J. Biotech. 8(22): 6301 - 6303. 